Review Article

\title{
Spatial Assessment of Hygiene and Sanitation Facilities of Unregulated Premises in Traditional Settlement of Ilorin Metropolis, Kwara State, Nigeria
}

\section{Adiama Babatunde Yusuf*, Henry Olawale Sawyerr, Alabede Iyabo Mubarakat, Habeeb Modupe Lateefat, Shehu Usman Mohammmed, Yusuf Olarewaju Rauf}

Department of Environmental Health, School of Allied Health and Environmental Science, Kwara State University, Malete, Nigeria

Email address:

yusufadiama2@gmail.com (A. B. Yusuf)

${ }^{*}$ Corresponding author

\section{To cite this article:}

Adiama Babatunde Yusuf, Henry Olawale Sawyerr, Alabede Iyabo Mubarakat, Habeeb Modupe Lateefat, Shehu Usman Mohammmed, Yusuf Olarewaju Rauf. Spatial Assessment of Hygiene and Sanitation Facilities of Unregulated Premises in Traditional Settlement of Ilorin Metropolis, Kwara State, Nigeria. Journal of Health and Environmental Research. Vol. 4, No. 3, 2018, pp. 105-112.

doi: $10.11648 /$ j.jher.20180403.14

Received: May 14, 2018; Accepted: July 23, 2018; Published: August 18, 2018

\begin{abstract}
Housing is one of the most important basic necessities of mankind which is known to tremendously affect human health and well-being. Water and sanitation projects are synergistic in producing health effects. The WHO estimates that $5.5 \%$ of the global disease burden is due to inadequate water and sanitation, while the duo is believed to be responsible for $88 \%$ of the 4 billion diarrheal cases, and the resultant 1.8 million deaths. This study examined the state of sanitation facilities and hygiene in traditional settlement of Ilorin community in Kwara state, Nigeria. The study was based on cross sectional descriptive design involving household head in core Ilorin metropolis. A semi-structured questionnaires and Observational checklist were distributed to three hundred and thirty (330) randomly selected household heads. The data was analyzed for descriptive and inferential at $5 \%$ level of significant. Informed consent was obtained. The mean age of respondents were $48 \pm 11.77$ years. Majority (42.7\%) of respondents occupied tenement type and $20 \%$ occupied traditional compound. Most (68.5\%) of respondents had sanitation facilities but only (35.4\%) were hygienic. Almost (92.1\%) of respondents experienced malaria and $77.7 \%$ also reported to have experienced cholera as health hazard associated with insanitary housing. Findings from this study indicated that family size, inspection of premises in the last one month, average monthly income and level of education influenced the sanitary status among the respondents $(\mathrm{p}<0.05)$. The availability of sanitation facility in the study area was appreciably high $68.5 \%$ but not hygienic.
\end{abstract}

Keywords: Sanitation, Unregulated Premises, Traditional Settlement, Hygiene

\section{Introduction}

A house provide physical framework in which human, social, economic and cultural resources are realized, enriched and integrated [1]. In the traditional African setting, housing is one of the greatly cherished material properties. This is partly due to some other vital cultural functions of houses which include protection of family cohesion and values, taking care of aged through extended family system, properties for inheritance and preservation of ancestral values among others [2].
According to (WHO, 2005) assessed the health profile of Nigerians and reported there is evidence that the key health indicators have either stagnated or worsened [3]. Many Nigerians suffer from one health situation or the other The National Strategic Health Development Plan (NSHDP) for the period 2010 to 2015 reported that the health status indicators for Nigeria are among the worst in the world and that health status of the population has declined, when compared with the indicators of a decade earlier [4].

In Nigeria, Environmental Health Officers (EHOs) 
previously known as Sanitary Officers or Public Health Superintendents working in the local governments has the responsibility to inspect all premises especially residential ones for the purpose of detecting and abating nuisances [5]. The Nigerian governments over the years initiated various moves to improve housing based on the resolutions adopted at the first United Nations Conference on Human Settlement held in Vancouver, Canada in, 1976. Apart from providing some regulations, the country has also formulated a National Housing Policy in 1991 which outlines strategies to ensure the provision of decent housing for the people. It must be understood that the issue of ensuring that the people live in healthy houses should not be a matter of policy alone but must be carried into action so as to limit risks to which the people are exposed. Constant monitoring of compliance against standards is surely one way of achieving this [6]. It is against this background that this study was carried out to assess the status of hygiene and sanitation facilities in unregulated housing being inhabited by the people whose economic and social lives transcend beyond their place of abode

\section{Literature Review}

Housing and health have become a topical issue in public health discourse for a very long time in view of the existence of increasing evidences as regards the potential effects of inadequate conditions of living premises on the inhabitants [6]. In Nigeria, a study done in major towns at different geopolitical zones revealed that about $20 \%$ of the population live in conducive and appropriate house and environment, $40 \%$ in overcrowded accommodations (both physical and psychological), while $30 \%$ have barely no structure of abode [7]. It has been observed that areas dominated by houses of poor standards records highest number of casualty both in terms of morbidity and mortality during disasters and epidemics. This is due to uncoordinated and coarse response of the people to emergencies, lack of adequate space to effective response, closeness of the housing structures to (one other especially in fire disasters) among other implicating factors [8]. A lot of various disease conditions within the crowded communities have been associated with poor ventilation and poor housing facilities. There is no doubt, that housing remains a basic human need. Its quality, cost, and availability are crucial to individual's quality of life. Also, the location, planning, layout and design make an important contribution to community spirit and identity, and are significant components of the social dimension of sustainable development [9]. Housing facilities are inadequate especially in rural and sub urban region. These regions are easily ignored by government because it is not seen as a priority for rural dwellers. Various coping strategies have been devised by the people to meet this basic need of life, part of which is resulted in overcrowding, which leads to some health consequences with varying morbidity and sometimes mortality [10]. Water and sanitation projects are synergistic in producing health effects. Study have shown that improved water sources reduce diarrhea morbidity by $21 \%$; improved sanitation reduces diarrhea morbidity by $37.5 \%$.

This synergy stems from the fact that both work together to reduce the pathogen load in the ambient environment, and in the interruption of the transmission of the pathogens. There has been massive investment in water projects as part of the effort to achieve the Millennium Development Goal on access to water and sanitation; the same cannot be said for sanitation projects [11].

According to WHO, people with poor health and negative wellbeing are more likely to live in poor housing and that improving housing conditions will improve health and save money. There are many diseases that have been linked with poor housing conditions [12]. Low-income earners have peculiar taste for tenement properties because of its low rent, though many of such properties lack basic infrastructure. The tenement type of residential properties usually consists of unit rooms flanking both sides of a central passage that connects the rooms to shared unit kitchens and toilets at the rear. Study done in Akure revealed that $86.77 \%$ of the respondents occupied this type of accommodation [13]. According to study on rat infestation in student hostel of a University in Nigeria linked cause of rat infestation with the level of indoor hygiene, sanitation being practiced by the students and overcrowding [14]. In Kwara State, the state Ministry of land and housing estimated in year 2000 , that about $70 \%$ of residents within the state lives in various improper housing conditions which includes substandard buildings, overcrowded homes, poor housing pattern and design (linked to poor ventilation) among others [15]. House design, poor state of maintenance and climatic condition of buildings environment can expose residents to excessive cold and attributed indoor cold conditions with poorer health and increased risk of cardiovascular disease [16]. Study has also established that some health disorder such as typhoid and paratyphoid fever, diarrhea, dysenteries, cholera, hookworm, ascariasis, viral hepatitis, guinea worm diseases, schistosomiasis, genito-urinary tract infections and many other intestinal and parasitic infections can be contacted through poor toilet facilities which may be a breeding ground for harmful bacteria, viruses and parasites [17]. It was reported by WHO in 2009 that those living in homes that are damp and moldy are at increased risk of experiencing health problems such as respiratory infections, allergic rhinitis and asthma. Presence of mold in building can pose health risk to babies, young children, elderly people, those with skin diseases and the people undergoing chemotherapy [12].

\section{The Study Area}

Ilorin is the capital city of Kwara State, Nigeria. It is located within the North Central of Nigeria with a distance of about $302 \mathrm{~km}$ North of Lagos and $475 \mathrm{~km}$ South of Abuja. Ilorin is made up of 3 Local Government Areas Vis; Ilorin East, Ilorin West and Ilorin South with their headquarters in Oke-Oyi, Wara-osin and Fufu respectively. 


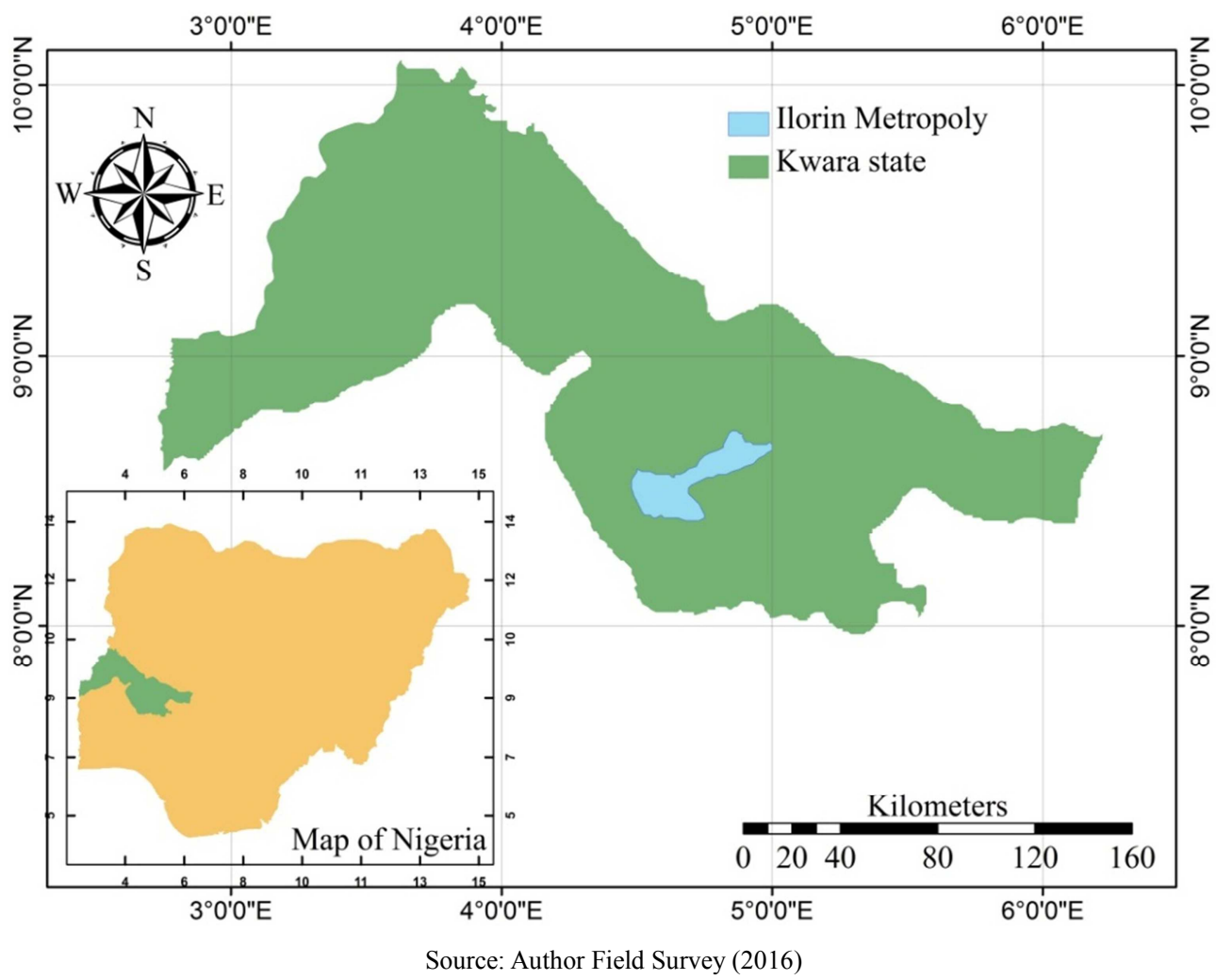

Figure 1. Showing the Map of Kwara State and the Study Area.

\section{Materials and Methods}

Descriptive cross sectional survey of all household heads resident in the study area was adopted. Multistage sampling techniques were used for the selection of 333 respondents in the three LGAs in Ilorin metropolis. Simple random sampling technique by balloting was used to select one (1) traditional settlement urban ward in each of the three LGAs in Ilorin metropolis. Systematic sampling techniques were used to select the number of respondents in each wards. In this study area human settlements consist of a collection of housing units which are called compounds. A compound could have an average of ten households. A sampling interval was obtained for each selected wards respectively. These methods were chosen because random probability sampling leads to the most representative samples of the population and every member of the population has a chance of being interviewed. The instruments for this study were interviewer administered semi-structured questionnaire and observational checklist were used by household head or its representative to report on the housing and health status of their households. Global positioning system (GPS) was also used, to have spot map of sanitary facilities present and hygiene condition of premises, as well as assessing the type and quality residential houses. The observational checklist were adopted from house - house sanitary inspection of premises form E. S 1 by the Federal Ministry of Environment was used by the researcher for comprehensive inspection in conjunction with environmental health officers (EHOs) to access the status housing condition of selected household.

\section{Results and Discussion}

\subsection{Demographic Characteristics of Respondents}

Table 1 shows the summary of the background information about the respondents. It is observed from the table that age distribution indicates only $13.0 \%$ of the respondents have their age above sixty (60) years; while most (34.2\%) are within the $50-59$ years age. Data on respondent showed that $14.5 \%$ had no formal education and $36.6 \%$ had secondary education as highest level of education. Majority of respondents $(60.0 \%)$ of the respondents had lived in traditional settlement of Ilorin for more than ten (10) years. It can therefore be inferred from this that they were born or had been staying for long. Report on household size indicates that $43.6 \%$ of respondents have between six (6) and ten (10) persons constituting members of their households. Followed by $21.5 \%$ having between one (1) and five (5) persons. This finding was in contrast which study done [18] where average household size was 5.9 and 4.9 persons in rural and urban areas and [19] respectively. Majority of respondents $(75.2 \%)$ had not the seen the presence of EHO's for regular inspection of premises in the last one month preceding the study.

Table 2 revealed that more than half $(59.2 \%)$ of respondents have their household monthly income above N 20,000 while only $8.5 \%$ earn N10, 000 monthly. This was dissimilar [19] where literature revealed $50.5 \%$ earned N20, 000 below as monthly income. 
Table 1. Socio-demographic characteristic of respondents.

\begin{tabular}{lll}
\hline Respondents variables & $\mathbf{( N = 3 3 0 )}$ & Frequency (\%) \\
\hline Age & $30-39$ & $75(22.7)^{*}$ \\
& $40-49$ & $99(30.0)$ \\
& $50-59$ & $113(34.2)$ \\
Sex & 60 yrs above & $43(13.0)$ \\
& Male & $260(78.8)$ \\
& Female & $70(21.2)$ \\
& Married & $271(80.9)$ \\
& Single & $23(6.9)$ \\
Marital Status & Widow & $15(4.5)$ \\
Educational level & Divorced & $8(3.4)$ \\
& Separated & $5(1.5)$ \\
& No formal & $48(14.5)$ \\
& Primary & $68(20.6)$ \\
& Secondary & $61(18.5)$ \\
& Tertiary & $111(36.6)$ \\
\hline
\end{tabular}

* The values in parenthesis are the percentage of the socio demographic variables

Table 2. Socio-demographic characteristic of respondents (Continuation).

\begin{tabular}{lll}
\hline Respondents variables & $\mathbf{( N = 3 3 0 )}$ & Frequency (\%) \\
\hline & Self-employed & $131(39.7)$ \\
& Civil servant & $77(23.3)$ \\
Occupation & Farming & $37(11.2)$ \\
& Artisan & $64(19.4)$ \\
& Unemployed & $21(6.40)$ \\
Size of Family & $1-5$ & $71(21.5)$ \\
& $6-10$ & $144(43.6)$ \\
Average monthly income (N) & $>10$ & $115(34.8)$ \\
& 10,000 & $28(8.5)$ \\
Regular inspection in last one month & 20,000 & $106(32.1)$ \\
& Above & $196(59.4)$ \\
Number of years already spent in the neighborhood & Yes & $82(24.8)$ \\
& No & $248(75.2)$ \\
& $1-5$ & $97(29.4)$ \\
& $6-10$ & $35(10.6)$ \\
\hline
\end{tabular}

Source: Field Survey, 2016

\subsection{Assessment of Residential Building Types and Quality of Sanitary Facilities}

\subsubsection{Residential Building Types}

Table 3 presents the characteristics of respondents' building type. The main type of residential properties found in the traditional settlement of Ilorin is tenement buildings $42.7 \%$ and $9.1 \%$ for both detached and semi-detached apartment. According to [13] low-income earners have peculiar taste for tenement properties because of its low rent, though many of such properties lack basic sanitary facilities. The tenement type of residential properties usually consists of unit rooms flanking both sides of a central passage that connects the rooms to shared unit kitchens and toilets at the rear. Sometimes the kitchen is attached to the structure while the conveniences (toilet and bathrooms) are in most cases detached from the main building. Figure 2 shows spatial distribution of residential building type in different local government of the study area.

Table 3. Types of residential building occupied by respondents $(N=330)$.

\begin{tabular}{lll}
\hline Variable & Frequency & Percentage \\
\hline Tenement building & 141 & 42.7 \\
Block of flat & 60 & 18.2 \\
Semi -detached house & 30 & 9.1 \\
Detached & 30 & 9.1 \\
Traditional compound & 69 & 20.9 \\
Total & 330 & 100.0 \\
\hline
\end{tabular}

Source: Author Field Survey, 2016 


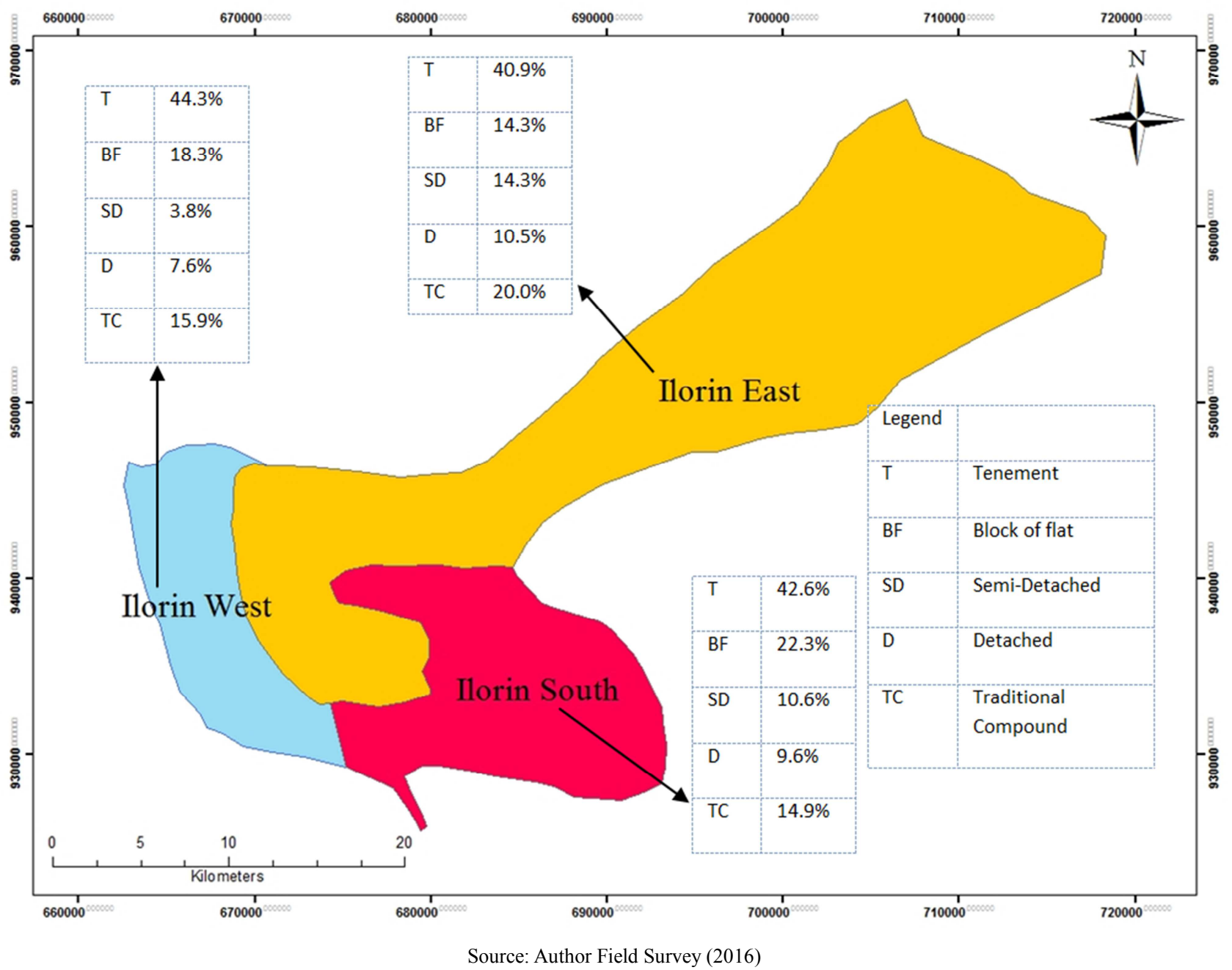

Figure 2. Spatial distribution of type of building in the study area.

\subsubsection{Qualities of Sanitary Facilities}

Table 4 presents result on availability of sanitary facilities. Majority of respondents (68.5\%) reported the presence sanitary facility (toilet facilities) in their house and out of which $35.4 \%$ were in good condition and $31.5 \%$ of the respondents no sanitary facilities. However, ignorant or no reason accounted for $40 \%$, cost $36.5 \%$ and $30.8 \%$ for lack of available space.
Figure 3 present distribution of toilet type, pour flush accounted for the major type of toilet facility $(27.9 \%)$ found in most home, pit latrine (18.8\%) water closet (16\%). However, open defecation were still in practice in some homes which accounted for $14 \%$ of the respondents' type of toilet use. Figure 4 also showed spatial distribution of toilet facilities present in different local government of the study area.

Table 4. Availability and quality of hygiene and sanitation facilities present in household.

\begin{tabular}{|c|c|c|c|}
\hline Variables & & Frequency & Percentage \\
\hline \multirow{2}{*}{ Availability of sanitary facility $(\mathrm{N}=330)$} & Yes & 226 & 68.5 \\
\hline & No & 104 & 31.5 \\
\hline \multirow{3}{*}{ Reasons for not having $(\mathrm{n}=104)$} & Lack of space & 32 & 30.8 \\
\hline & Cost & 38 & 36.5 \\
\hline & No reason & 42 & 40.4 \\
\hline \multirow{2}{*}{ Hygienic status of the sanitation facility $(\mathrm{n}=226)$} & Good & 80 & 35.4 \\
\hline & $\mathrm{Bad}$ & 146 & 64.6 \\
\hline
\end{tabular}




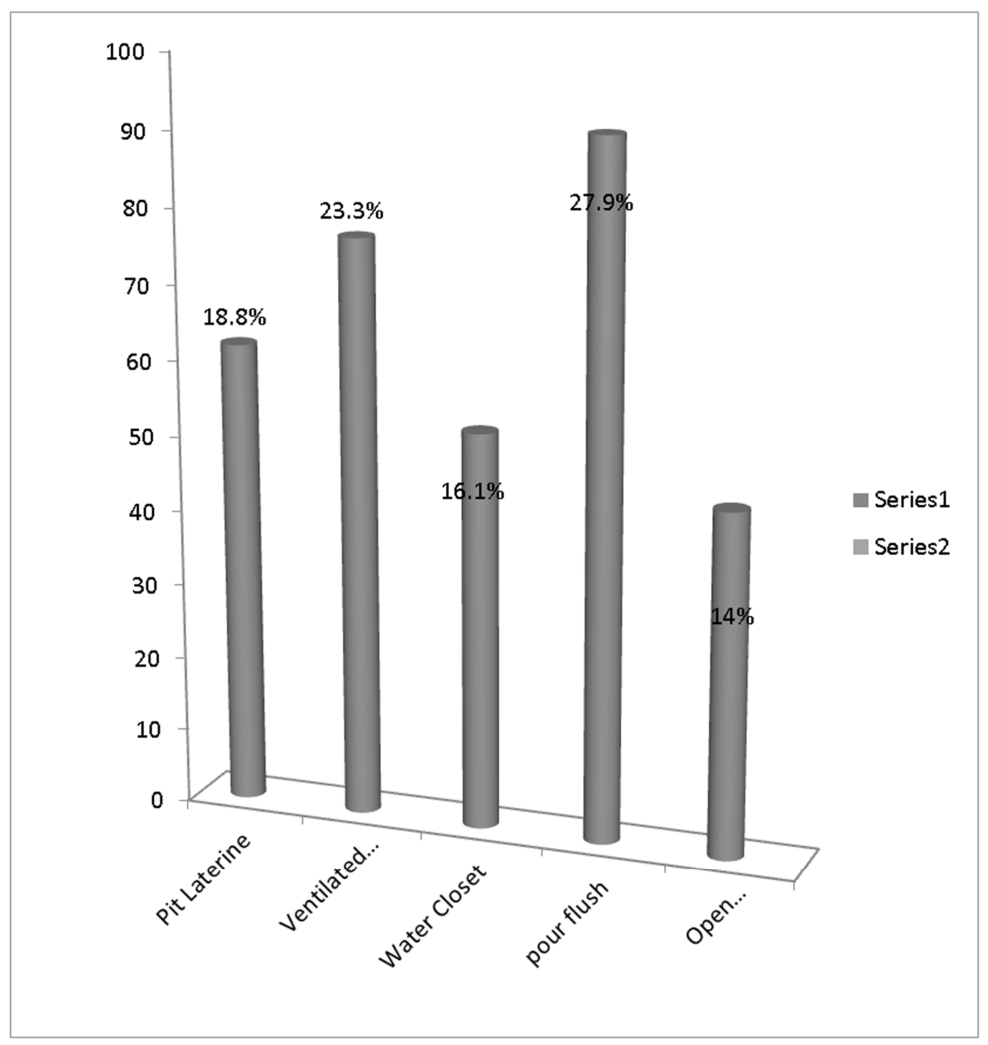

Source: Author Field Survey, 2016

Figure 3. Showing respondents' type of toilet facility use.

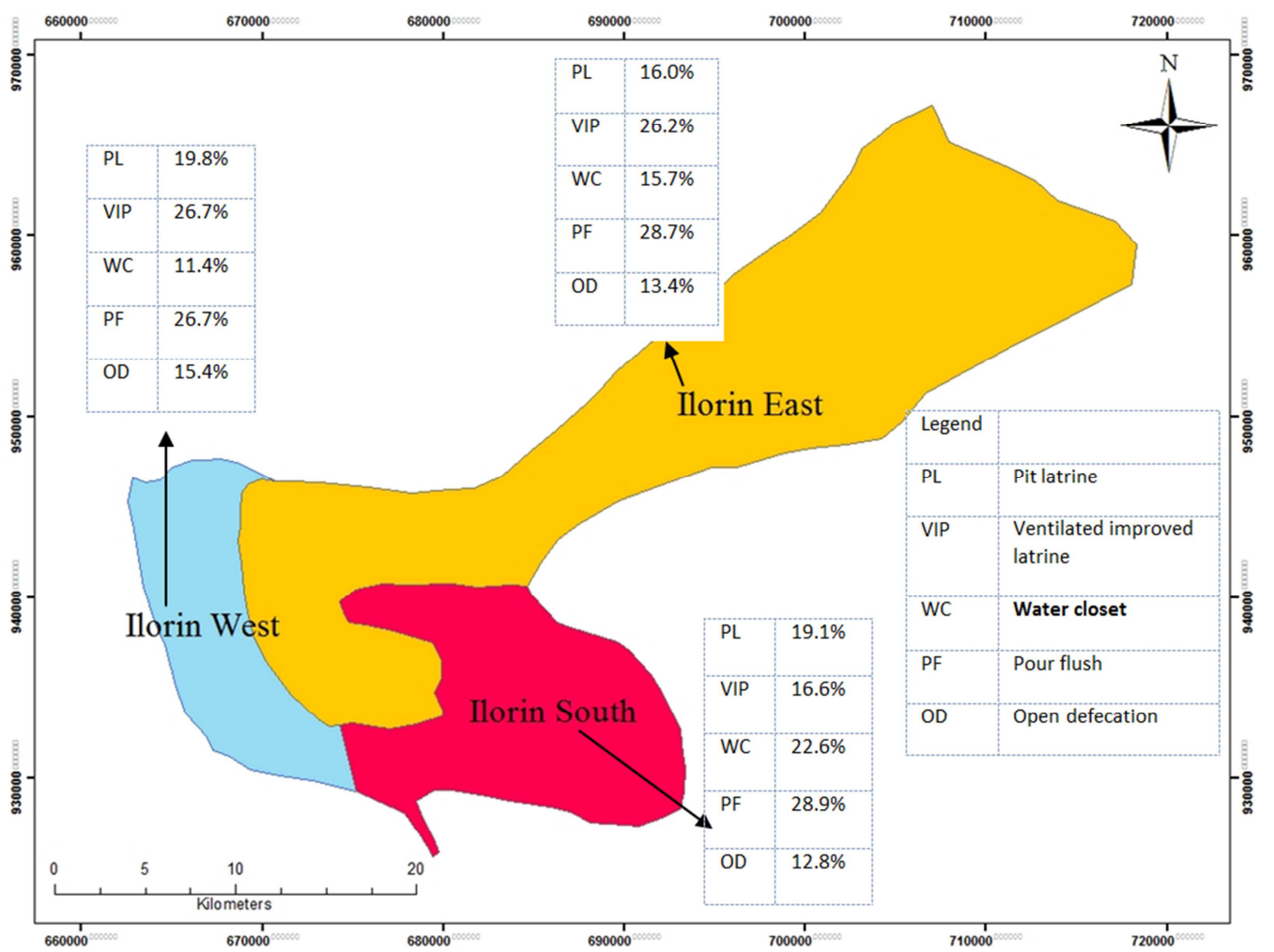

Figure 4. Spatial distribution of type of sanitary facility present (Toilet) in the study area. Source: Author Field Survey (2016).

\subsubsection{Sources of Water}

Majority of the respondents $(60 \%)$ had their water source from well and pipe borne water were least source accounted for $11.8 \%$. On account of the proximity of the source $71.8 \%$ respondents reported $<30 \mathrm{~m}$ from their house. On how 
frequent was the supply of the water source, $65.8 \%$ reported that the source were regular with less than one percent said twice monthly and only $7.9 \%$ of the respondents reported that, the source were not reliable as shown in table 5 .

Table 5. Respondents sources of water for domestic use.

\begin{tabular}{lll}
\hline Variables & Frequency & Percentage \\
\hline Sources of water & & \\
Well & 198 & 60 \\
Borehole & 93 & 28.2 \\
Stream & 0 & 0.00 \\
Pipe borne & 39 & 11.8 \\
Proximity of source & 237 & 71.8 \\
$<30 \mathrm{~m}$ & 93 & 28.2 \\
$>30$ & 217 & 65.8 \\
Frequency of the supply & 85 & 25.8 \\
Regular & 2 & 0.6 \\
Daily & 26 & 7.9 \\
Twice monthly & 330 & 100.0 \\
Not reliable & & \\
Total & & \\
\hline
\end{tabular}

Source: Author Field Survey, 2016

\subsection{Health Condition of Respondents}

An enquiry into knowledge of respondents on relationship between health effect of insanitary housing and housing standard. Report from table 6, revealed that majority (89.7\%) of respondents knows the relationship between health and housing standard. Majority of respondents $(88.2 \%)$ said that diseases can be transmitted due to insanitary housing conditions. Only $24 \%$ of the respondents were found to have good hand washing behaviour.

Table 7 presents the health related problems experienced among the respondents' households and the frequency. Majority of respondents $(92.1 \%)$ had experienced malaria as most prevalent health challenge complained due to insanitary housing condition and $77.7 \%$ reported to have experienced cholera while only $13.7 \%$ reported cough which was lower compared to $31.3 \%$ reported and about $92.3 \%$ of sampled households in rural Akwa Ibom State reported the occurrence of at least one respiratory symptom [20]. In another study it was reported that $(29.6 \%)$ malaria fever as the most experienced health hazards by respondents, followed by typhoid fever $(23.5 \%)$, cholera $(9.1 \%)$, diarrhea $(11.6 \%)$ which was dissimilar to this present study [21].

Majority of the respondents got to know of possible consequence of insanitary house condition from radio $89.6 \%$, medical doctor $46.6 \%$, EHOs $41.2 \%$ and the least $(25.2 \%)$ from mosque as presented in table 8 .

Table 6. Knowledge on some health related effect of insanitary housing experienced by the respondents.

\begin{tabular}{llll}
\hline Variable & & Frequency (\%) \\
\hline Relationship with health and housing standard & & $295(89.7)^{*}$ & $35(10.3)$ \\
Can diseases be transmitted due to insanitary housing & & Yes & $291(88.2)$ \\
Hand washing behaviour $(\mathrm{N}=330)$ & 78 & No & $39(11.8)$ \\
Good (8 10 points) & 54 & Yes & $(24.0)$ \\
Moderate (5 7 points) & 198 & No & $(16.0)$ \\
Bad (/<4 points) 1 & & $(60.0)$ \\
Total & & $330(100.0)$ \\
\hline
\end{tabular}

Source: Author Field Survey, 2016

Table 7. Some health related effect of insanitary housing experienced by the respondent $[n=291$.

\begin{tabular}{lll}
\hline Health effects experienced & Frequency & Percentage* \\
\hline Diarrhea & 140 & 48.1 \\
Malaria & 268 & 92.1 \\
Cough & 40 & 13.7 \\
Cholera & 226 & 77.7 \\
Asthma & 87 & 29.9 \\
\hline
\end{tabular}

*Multiple responses

Source: Author Field Survey, 2016

Table 8. Respondent sources of information on possible consequence of insanitary housing condition $(N=330)$.

\begin{tabular}{lll}
\hline Sources of information & Frequency & Percentage* $^{*}$ \\
\hline Television & 102 & 30.9 \\
Radio & 296 & 89.6 \\
EHOs & 136 & 41.2 \\
Mosque & 83 & 25.2 \\
Church & 104 & 31.5 \\
Medical Doctor & 154 & 46.6 \\
\hline
\end{tabular}

*Multiple response

Source: Author Field Survey, 2016

\section{Conclusion and Recommendation}

Conclusion: This study has examined the spatial pattern of housing quality and sanitary facilities in traditional settlement of Ilorin Metropolis. There was access to sanitation facility in the study area. However, Open defecation were still in practice and hand washing behavior remains poor such that the prevalence of diarrhea is still high in the community. Tenement and traditional housing compound were the major type of residential building occupied by most respondents. Overcrowding, due to the fact that people cannot afford to pay high house rent, therefore there is increase in the number of persons living in a room with squatters which further deteriorate the facilities in the house like toilet, bathroom, and creating other social and economic problems. Sanitary services in the areas need urgent attention, particularly water supply and waste disposal facilities. However, mini-water-works or boreholes and public toilets in strategic places in the area are recommended under Urban Basic Service Program. Hygiene education and social marketing of sanitation facilities especially hand washing campaign are 
hereby advised to promote hygiene practices and improve access. Findings of this study serves as a "wake-up call" to the Kwara State Government to exhibit an active interest in training and retraining of EHOs and provide necessary resources that will enhance their performance in discharging their statutory responsibility. Also, EHOs would be needed to reawaken the unconcerned attitude of the residents towards sanitary laws and regulations through education.

\section{References}

[1] Andrzenjewski A. Role of Public Health Agencies. Textbook of Environmental Challenges, Indonesia, Azaca press, 2005, pg5-7.

[2] Marshy O. A. Effect of Overcrowding. Refugee Camp In Leu, Gaza, West bank, 2004, 34.

[3] Olukolajo M. A., Adewusi, A. O. and Ogungbenro, M. T. (2013), "Influence of Housing Condition on the Health Status of Residents of Urban Core of Akure, Nigeria", International Journal of Development and Sustainability, Vol. 2No. 2, pp. 1567-1579.

[4] NSHDP (2010), National Strategic Health Development Plan (NSHDP) 2010-2015. Federal Ministry of Health. Available at http://www.healthresearchweb.org/files/NSHDP.pdf.

[5] National Environmental Health Practice Regulation (2016) accessed from www.ehorecon.gov.ng/Environmental-Health-Officers-Registr ation-Council-of-Nigeria, Act 11 of 2002.

[6] P. Bamigboye Abiodun and A. Ogunkeyede Segun, 2005. An Assessment of Housing Status in a Typical Nigerian Town. Journal of Applied Sciences, 5: 437-440.

[7] AO Yoade (2016). Economic and Environmental Studies, Housing Preference of Residents in Ile-Ife, Nigeria.

[8] Sanmi Adeoti., Akintunde T. B (2004). Poverty Implications on Natural Disasters Occurrence in Nigeria The International Journal Of Engineering And Science (IJES) Volume 3 Issue 10 Pages 08-14 2014 ISSN (e):2319-1813 ISSN (p):2319 1805 www.theijes.com.

[9] Abdullahi B. C. (2010) Nigeria's Housing Policy and Public-Private Partnership (PPP) Strategy: Reflection in Achieving Home Ownership for Low- Income Group in Abuja-Nigeria. Urban Dynamics and Housing Change 22nd International Housing Research Conference, 4-7 July, 2010. Istanbul.
[10] Bonnefoy, X. (2007). Inadequate Housing and Health: An overview. International Journal of Environment and Pollution, (3) 411-429.

[11] United Nations Millennium Project. Health, dignity, and development: what will it take? Accessed on $20^{\text {th }}$ of April 2016. from Global Water, Sanitation and Hygiene fast fact.

[12] WHO (2009), Global Health Risks -World Health Organisation.www.who.int/healthinfo/... /Global Health Risks_ report_full.pdf.

[13] Oni, A. O. and Durodola, O. D. (2010),“ Disputes resolution amongst residents of Tenement properties in Lagos, Nigeria", Global Jour. of Engg. and Tech, Vol. 3, No. 4, pp. 661- 670.

[14] Bamigboye, A. P. (2006), "Rat Infestation in a Typical Nigerian University Halls of Residence: Implications for Hygiene and Sanitation", Research Journal of Agriculture and Biological Sciences, Vol. 2No. 6, pp. 328-331.

[15] Housing and Urban Development: Housing requirement in the state. http://www.kwarastate.gov.ng/housing/ accessed in April 2016: Kwara State.

[16] Krieger, J. and Higgins, D. L. (2002), "Housing and Health: Time Again for Public Health Action", Am J Public Health, Vol. 92No. 5, pp. 758-768.

[17] Agbo, H. A., Envuladu, E. A., Adah, U. G. and Zoakah, A. I. (2012), "An assessment of toilet facilities in secondary schools in Jos North Local Government Area of Plateau State", Greener Journal of Educational Research, Vol. 2 No. 4, pp. 091- 094.

[18] National Bureau of Statistics - Nigeria - General Household Survey-Panel Wave 3 (Post Planting) 2015-2016, Third round. NGA-NBS-NGHPS-2016-v1.0.

[19] Olukolajo, M. A., Adewusi, A. O. and Ogungbenro, M. T. (2013), "Influence of Housing Condition on the Health Status of Residents of Urban Core of Akure, Nigeria", International Journal of Development and Sustainability, Vol. 2No. 2, pp. 1567-1579.

[20] Udoh, U. Uyanga J. (2013), Housing Conditions and Health in Rural Nigeria: A Study of Akwa Ibom State. Journal of Research on Huminities and Social Sciences. ISSN (Paper) 2224-5766 ISSN (Online) 2225-0484.

[21] Owoeye, J. O. and Omole, F. K. (2012), "Analysis of Housing Condition and Neighbourhood Quality of Residential Core of Akure, Nigeria", Mediterranean Journal of Social Sciences, Vol. 3 No. 3, pp. 471 -481. 